Journal of Animal and Feed Sciences, 19, 2010, 368-378

\title{
Carcass quality characteristics of Hair Goat and Saanen $\times$ Hair Goat crossbred kids from intensive production system ${ }^{*}$
}

\author{
A. Yilmaz ${ }^{1,3}$, B. Ekiz', M. Ozcan'1, C. Kaptan², H. Hanoglu², \\ M. Yildirir ${ }^{2}$ and O. Kocak ${ }^{1}$
}

\author{
'Istanbul University, Veterinary Faculty, \\ Department of Animal Breeding and Husbandry \\ Avcilar, Istanbul, 34 320, Turkey \\ ${ }^{2}$ Marmara Livestock Research Institute, Bandirma \\ Balikesir, 10 230, Turkey
}

(Received 9 April 2009; revised version 19 February 2010; accepted 16 August 2010)

\begin{abstract}
The aim of this study was to investigate the effects of crossbreeding indigenous Hair Goat with Saanen on carcass quality characteristics of kids under an intensive production system. Twenty four male kids from purebred Hair Goat and Saanen $\times$ Hair Goat $\left(\mathrm{F}_{1}\right.$ and $\left.\mathrm{B}_{1}\right)$ crossbred genotypes were weaned at 75-80 days of age and fattened for 56 days. Slaughter weights were 17.42, 18.22 and 16.79 $\mathrm{kg}$ and chilled carcass weights were $6.49,7.29$ and $6.69 \mathrm{~kg}$ for Hair Goat, $\mathrm{F}_{1}$ and $\mathrm{B}_{1}$, respectively. The organ weights, dressing percentages, $M$. longissimus dorsi area, fatness parameters, carcass measurements, subcutaneous fat colour, carcass joint weights and percentages and dissected leg compositions of kids were similar $(\mathrm{P}>0.05)$ in genotype groups. It is concluded that crossbreeding indigenous Hair Goat with Saanen at $\mathrm{F}_{1}$ and $\mathrm{B}_{1}$ levels did not result in any improvement in quality carcass production of kids under an intensive production system.
\end{abstract}

KEY WORDS: crossbreeding, carcass quality, fattening, Saanen goat, Hair Goat

\footnotetext{
* Supported by the Research Fund of Istanbul University, Project No. 598/15122006, UDP1985/18012008, and Republic of Turkey, Ministry of Agriculture and Rural Affairs, General Directorate of Agricultural Research, Project No. TAGEM/07/08/04/03

${ }^{3}$ Corresponding author: e-mail: yalper@istanbul.edu.tr
} 


\section{INTRODUCTION}

Goat breeding in Turkey is an essential traditional way of life for indigeneous people living in rural areas. Goat population in Turkey is estimated at 6.3 million heads (Anonymous, 2008). The great majority (96\%) of this population is Hair Goat which is being bred in different climatic conditions in all regions of Turkey (Kaymakci, 2006). Hair Goat is a low producing indigenous breed; however, it can continue its living and production by exploiting low potential rural areas and wastelands which cannot be used for any other kind of cultivation (Yalcin, 1986; Boyazoglu and Morand-Fehr, 2001).

Typical dairy products are being produced from goat milk in certain regions of Turkey. Owing to their remarkable taste and aroma, products like goat cheese are being sold at high price in the market. However, the quantity of milk produced from indigenous Hair Goat is seemingly low (60-70 kg per lactation) (Yalcin, 1986). In order to increase the amount of milk produced from goats, Hair Goats are being widely crossbred with Saanen. Crossbreeding is particularly done in the Western Anatolia and European part (Thrace) of Turkey (Kaymakci, 2006).

The main income acquired from goat breeding in Turkey is provided by milk and kid selling (Kosum et al., 2003). In the traditional production system, to obtain more marketable milk from goats, kids are weaned at 2-3 months of age (Gursoy, 2006). Meat from early weaned kids is very much appreciated by the people in certain regions of Turkey as it is the case in most of the Mediterranean countries (Boyazoglu and Morand-Fehr, 2001). Kids are usually slaughtered at early ages without further fattening, hence low weighing carcasses are produced. The same system is also being applied to kids obtained from crossbreeding with Saanen. Therefore, it can be deduced that in this production system meat production potential of early weaned kids is not fully utilized.

In the present study, the effects of genotype on carcass quality characteristics of purebred Hair Goat and Saanen $\times$ Hair Goat $\left(\mathrm{F}_{1}\right.$ and $\left.\mathrm{B}_{1}\right)$ crossbred kids from intensive production system were investigated. It was aimed to produce knowledge for the genotype choice for kid carcass production in the region.

\section{MATERIAL AND METHODS}

The research protocol of the current study was approved by the Ethic Committee of Istanbul University Veterinary Faculty (Approval number: 2006/173).

\section{Animals and fattening procedure}

The study was conducted at Marmara Livestock Research Institute in 2006 and 
2007. Does from Saanen $\times$ Hair Goat $\left(F_{1}\right)$ cross and purebred Hair Goat genotypes were reared in the institute. These does were bred with purebred Saanen bucks in fall 2006. $B_{1}$ crossbred kids were produced by mating of $F_{1}$ does with purebred Saanen bucks. After birth, kids were kept with their mothers in individual pens for 3 days. In this period, kids were identified and birth date, birth weight, sex, birth type and all the pedigree information of kids were recorded. Then a flock composed of suckling kids and their mothers was formed. During the suckling period, all the kids were kept indoors, and they also received grass hay and kid grower feed in addition to their mother's milk. Saanen $\times$ Hair Goat $\left(\mathrm{F}_{1}\right.$ and $\left.\mathrm{B}_{1}\right)$ kids were weaned at 14 May, 2007. After weaning, seven and eight kids from $F_{1}$ and $B_{1}$ genotypes, respectively, were selected for fattening. Kids chosen for the fattening programme from these genotypes were male, singleton and born in the middle of the kidding season. Mean weaning age of chosen kids for fattening were 77.1 days for $F_{1}$ crosses and 76.8 days for $B_{1}$ crosses. On the other hand nine purebred male Hair Goat kids were purchased from a commercial farm in the same region. Mating and kidding seasons and weaning date of Hair Goat genotype were similar to that of crossbred genotypes. Fattening pens for each genotype group (totally, three pens) were built in indoor, and kids from the same genotype were placed into the same pen. After a week of adapting to the feed, the kids were fattened for 56 days. Concentrate feed, which was given ad libitum to fattening kids, was produced at the institute. Also each kid received $100 \mathrm{~g}$ /day of lucerne hay during the fattening period. Diet samples were analysed for dry matter (DM) and crude cellulose (CC) according to AOAC (1984) methods. Crude protein was calculated from Kjcldahl $\mathrm{N}$ values as total $\mathrm{N} \times 6.25$ (AOAC, 1984). Ether extract was determined using Soxhlet extraction procedure with anhydrous diethyl ether as the non-polar solvent. Ash was analysed by ashing at $550^{\circ}, 6 \mathrm{~h}$ in a furnace. Ingredients and composition of concentrate feed used in the study are given in Table 1.

Table 1. Ingredients and chemical composition and nutritive value of concentrate feed

\begin{tabular}{lc}
\hline Item & $\%$ \\
\hline Ingredients, \% & \\
barley & 74.00 \\
sunflower cake & 24.00 \\
calcium carbonatc & 1.40 \\
salt & 0.50 \\
vitamin + mineral premix & 0.10 \\
Chemical composition, \% as fed & \\
dry matter & 87.01 \\
crude protein & 15.28 \\
cther extract & 1.97 \\
crude cellulose & 10.04 \\
ash & 2.95 \\
Metabolizable energy, Kcal/kg & 2470 \\
\hline
\end{tabular}


Slaughtering procedures and carcass quality measurements

At the end of 56-day fattening period, kids were slaughtered after electrical stunning at experimental slaughter unit of Marmara Livestock Research Institute. Preslaughter liveweight was recorded after $12 \mathrm{~h}$ fasting with free access to water. After the slaughter, head, skin, feet, lungs and trachea, liver, heart, spleen, omental and mesenteric fat, full gastrointestinal tract and testicles were removed, and then hot carcass was weighed. In order to estimate empty body weight, gastrointestinal tract content was removed, and the weight of empty gastrointestinal tract was recorded. The carcasses were chilled at $4^{\circ} \mathrm{C}$ for $24 \mathrm{~h}$, and then weighed to determine chilled carcass weights. Dressing percentage was calculated using slaughter weight (DP1) and empty body weight (DP2).

Subcutaneous fat colour was measured at $24 \mathrm{~h}$ post-mortem using the $\mathrm{L}^{*}, \mathrm{a}^{*}$, b* system by a Minolta CR 400 colorimeter (Minolta Camera Co., Osaka, Japan). Measurements were applicd at $2 \mathrm{~cm}$ latcral point from vertebral column between the last thoracic and first lumbar vertebrae. Chilled carcasses were also classified for fatness and conformation using 1-15 scales at $24 \mathrm{~h}$ after slaughter as described by Ruiz de Huidobro et al. (2004). Furthermore, body length, back length, long leg length, chest depth, chest circumference, buttock circumference, internal chest depth were measured according to Yilmaz et al. (2002). Chilled carcasses were then split along the vertebral column into left and right halves. The right side of carcass was separated into neck, shoulder, flank, ribs, long leg and tail joints according to the methodology described by Colomer-Rocher et al. (1987). Kidney and kidney knob and channel fat (KKCF) were removed from half carcass and weighed. $M$. longissimus dorsi (MLD) area and backfat thickness were measured between the last thoracic and first lumbar vertebrae according to Boggs and Merkel (1993).

Long leg joint from right side of carcass was used to determine tissue composition and was dissected into muscle, subcutaneous fat, intermuscular fat, bone and other tissues (major blood vessels, tendons, larger nerves and lymph nodes) according to the procedures of Fisher and de Boer (1994).

\section{Statistical analyses}

In order to determine the effect of genotype on carcass quality characteristics, one-way ANOVA was performed using SPSS 10.0 statistical package (SPSS, 1999). If the effect of genotype was found significant, Duncan's multiple range tests were used to evaluate the significance of the difference. 


\section{RESULTS AND DISCUSSION}

Slaughter characteristics. Slaughter results of Hair Goat and Saanen $\times$ Hair Goat $\left(F_{1}\right.$ and $\left.B_{1}\right)$ crossbred kids are presented in Table 2. The differences between kid genotypes in terms of slaughter weight and organs weights were not statistically significant $(P>0.05)$. Of the three genotypes, Hair Goat kids had the highest $(\mathrm{P}<0.05)$ weight for full stomach and gastrointestinal tract content. These differences might indicate that indigenous Hair Goat kids could consume more feed in intensive fattening than crossbred kids. Higher consumption of feeds, however, did not affect the weight gain. This might indicate poor feed conversion efficiency for Hair Goat.

Table 2. Means and standard errors for certain slaughter characteristics in Hair Goat and Saanen $\times$ Hair Goat crossbred $\left(F_{1}\right.$ and $\left.B_{1}\right)$ kids

\begin{tabular}{|c|c|c|c|c|c|c|c|}
\hline \multirow{2}{*}{ Item } & \multicolumn{2}{|c|}{ Hair Goat } & \multicolumn{2}{|c|}{ Saanen $\times$ Hair, $F_{1}$} & \multicolumn{2}{|c|}{ Saanen $\times$ Hair, B } & \multirow[t]{2}{*}{$F$} \\
\hline & mean & $\overline{\mathrm{SE}}$ & mean & $\mathrm{SE}$ & mean & SE & \\
\hline Slaughter weight, $\mathrm{kg}$ & 17.42 & 0.76 & 18.22 & 2.29 & 16.79 & 1.76 & $0.186^{\mathrm{Ns}}$ \\
\hline Head weight, $\mathrm{kg}$ & 1.17 & 0.05 & 1.22 & 0.11 & 1.15 & 0.06 & $0.261^{\mathrm{NS}}$ \\
\hline Skin, kg & 1.02 & 0.07 & 1.09 & 0.16 & 0.89 & 0.09 & $0.829^{\mathrm{NS}}$ \\
\hline Feet, $\mathrm{kg}$ & 0.48 & 0.02 & 0.56 & 0.06 & 0.53 & 0.04 & $1.086^{\mathrm{NS}}$ \\
\hline Lungs and trachea, $g$ & 222.22 & 7.34 & 284.00 & 32.10 & 332.50 & 55.90 & $2.458^{\mathrm{NS}}$ \\
\hline Liver, $g$ & 323.56 & 21.62 & 369.43 & 48.18 & 440.50 & 45.73 & $2.468^{\mathrm{Ns}}$ \\
\hline Heart, g & 72.44 & 4.04 & 82.00 & 8.53 & 76.00 & 6.51 & $0.575^{\text {Ns }}$ \\
\hline Spleen, $g$ & 49.33 & 4.98 & 37.14 & 5.60 & 33.25 & 4.17 & $3.093^{\text {NS }}$ \\
\hline Omental and mesenteric fat, $g$ & 134.89 & 40.43 & 162.86 & 58.46 & 99.50 & 20.93 & $0.558^{\mathrm{NS}}$ \\
\hline Full stomach, g & $3980.44^{a}$ & 197.22 & $3078.57^{\mathrm{b}}$ & 362.92 & $2538.50^{\mathrm{b}}$ & 344.02 & $6.354^{* *}$ \\
\hline Empty stomach, $\mathrm{g}$ & 730.22 & 36.19 & 778.86 & 112.56 & 744.75 & 97.64 & $0.086^{\mathrm{NS}}$ \\
\hline Full intestines, $\mathrm{g}$ & 1706.67 & 76.70 & 2090.57 & 226.85 & 2034.50 & 241.81 & $1.284^{\mathrm{NS}}$ \\
\hline Empty intestines, $\mathrm{g}$ & 1140.44 & 75.09 & 1358.57 & 141.74 & 1300.25 & 116.61 & $1.093^{\mathrm{NS}}$ \\
\hline Gastrointestinal tract content, $\mathrm{g}$ & $3816.44^{a}$ & 167.75 & $3031.71^{\text {ab }}$ & 317.34 & $2528.00^{b}$ & 349.43 & $5.765^{*}$ \\
\hline Testicle, $\mathrm{g}$ & 72.89 & 12.13 & 112.00 & 27.74 & 112.00 & 22.65 & $1.261^{\mathrm{NS}}$ \\
\hline
\end{tabular}

The slaughter weights of Hair Goat and Saanen $\times$ Hair Goat $F_{1}$ and $B_{1}$ kids were $17.42,18.22$ and $16.79 \mathrm{~kg}$, respectively. These results were within the range reported for several combinations of Boer, Angora, Saanen and Feral breeds to produce Capretto carcasses (Dhanda et al., 2003). Similar to the current study, Kosum et al. (2003) did not find the significant effect of genotype on slaughter weight after intensive fattening in Saanen and Bornova breeds. However, there are also studies reporting significant genotype effects on slaughter weight in kids slaughtered at similar ages after intensive fattening (Oman et al., 1999; 
Kadim et al., 2003).

Chilled carcass characteristics and fat colour. Kid genotype had no significant effect on chilled carcass characteristics, like carcass weight, dressing percentages, chilling loss, conformation and fatness scores, MLD section area, backfat thickness and carcass measurements (Table 3 ). The chilled carcass weights of Hair Goat and Saanen $\times$ Hair Goat $F_{1}$ and $B_{1}$ crossbred kids were 6.49, 7.29 and $6.69 \mathrm{~kg}$, respectively. Similar cold carcass weights of genotype groups in the present study could be due to similar slaughter weights of these groups. Similar to the results from the present study, no significant genotype effect on chilled carcass weights of Capretto carcasses $(6.2-7.0 \mathrm{~kg})$ was reported by Dhanda et al. (1999a) for crossbreds of Boer, Angora, Saanen and Feral breeds. The chilled carcass weights of the kids in the present study were similar to those reported for Capretto carcasses.

Table 3. Means and standard errors for certain chilled carcass characteristics, carcass measurements and fat colour parameters in Hair Goat and Saanen $\times$ Hair Goat crossbred $\left(\mathrm{F}_{1}\right.$ and $\left.\mathrm{B}_{1}\right)$ kids

\begin{tabular}{|c|c|c|c|c|c|c|c|}
\hline \multirow{2}{*}{ Item } & \multicolumn{2}{|c|}{ Hair Goat } & \multicolumn{2}{|c|}{ Saanen $\times$ Hair, $F_{1}$} & \multicolumn{2}{|c|}{ Saanen $\times$ Hair, $B_{1}$} & \multirow{2}{*}{$\mathrm{F}$} \\
\hline & mean & SE & mean & SE & mean & SE & \\
\hline Chilled carcass weight, $\mathrm{kg}$ & 6.49 & 0.39 & 7.29 & 1.14 & 6.69 & 0.78 & $0.276^{\mathrm{NS}}$ \\
\hline Dressing percentage-1 DP1, $\%$ & 37.11 & 0.85 & 39.09 & 1.30 & 39.58 & 0.55 & $2.192^{\mathrm{NS}}$ \\
\hline Dressing percentage-2 DP $2, \%$ & 47.55 & 0.82 & 47.09 & 1.22 & 46.47 & 0.80 & $0.354^{\mathrm{NS}}$ \\
\hline Chilling loss, $\mathrm{g}$ & 289.78 & 7.03 & 318.57 & 28.12 & 321.50 & 21.21 & $0.884^{\mathrm{NS}}$ \\
\hline Chilling loss, $\%$ & 4.38 & 0.25 & 4.47 & 0.33 & 4.77 & 0.25 & $0.562^{\mathrm{NS}}$ \\
\hline Conformation score ( $1-15$ scale) & 1.33 & 0.17 & 1.57 & 0.20 & 1.63 & 0.32 & $0.450^{\mathrm{NS}}$ \\
\hline Fatness score ( $1-15$ scale) & 1.44 & 0.24 & 1.57 & 0.20 & 1.63 & 0.32 & $0.131^{\mathrm{NS}}$ \\
\hline MLD section area, $\mathrm{cm}^{2}$ & 5.97 & 0.41 & 6.02 & 0.79 & 5.44 & 0.70 & $0.258^{\mathrm{NS}}$ \\
\hline Backfat thickness, mm & 0.26 & 0.05 & 0.24 & 0.07 & 0.28 & 0.06 & $0.073^{\mathrm{NS}}$ \\
\hline Body length, $\mathrm{cm}$ & 47.62 & 0.45 & 48.00 & 1.78 & 48.09 & 1.27 & $0.046^{\mathrm{NS}}$ \\
\hline Back length, cm & 48.97 & 0.35 & 50.16 & 1.67 & 49.98 & 1.26 & $0.337^{\mathrm{NS}}$ \\
\hline Long leg length, $\mathrm{cm}$ & 34.82 & 0.46 & 35.49 & 1.14 & 34.84 & 0.79 & $0.214^{\mathrm{NS}}$ \\
\hline Chest depth, cm & 21.51 & 0.27 & 22.26 & 0.93 & 22.10 & 0.61 & $0.431^{\mathrm{NS}}$ \\
\hline Chest circumference, $\mathrm{cm}$ & 55.38 & 0.74 & 57.13 & 2.39 & 56.60 & 1.78 & $0.303^{\mathrm{NS}}$ \\
\hline Buttock circumference, $\mathrm{cm}$ & 37.29 & 0.50 & 37.79 & 2.03 & 36.84 & 1.51 & $0.110^{\mathrm{NS}}$ \\
\hline Internal chest depth, $\mathrm{cm}$ & 15.53 & 0.24 & 15.63 & 0.59 & 15.84 & 0.56 & $0.117^{\mathrm{NS}}$ \\
\hline Lightness (L*) & 64.86 & 1.14 & 61.92 & 1.34 & 62.26 & 0.96 & $2.054^{\mathrm{NS}}$ \\
\hline Redness $\left(a^{*}\right)$ & 4.76 & 0.64 & 5.55 & 0.37 & 5.62 & 0.29 & $1.012^{\mathrm{NS}}$ \\
\hline Yellowness (b*) & 6.61 & 0.62 & 6.36 & 0.90 & 5.59 & 0.95 & $0.434^{\mathrm{NS}}$ \\
\hline
\end{tabular}

In the present study, the dressing percentages based on slaughter weight ranged from 37.11 to $39.58 \%$. Cameron et al. (2001) also reported non-significant 
differences in dressing percentage between Boer $\times$ Spanish, Spanish and Boer $\times$ Angora kids in intensive fattening. The dressing percentages based on empty body weight in Hair Goat and Saanen $\times$ Hair Goat $\left(\mathrm{F}_{1}\right.$ and $\left.\mathrm{B}_{1}\right)$ crossbred kids ranged from 46.47 to $47.55 \%$. Similar to the current study, Dhanda et al. (1999a) and Santos et al. (2007) for Capretto carcasses reported no significant effect of genotype on dressing percentages based on empty body weight. Different studies (Johnson and McGowan, 1998; Kosum et al., 2003; Ekiz et al., 2010) reported higher dressing percentages than the ones found in the present study. These differences might be attributed to variation in slaughter weight between studies.

Conformation and fatness scores and body measurements like back length, body length and chest circumference, were numerically higher in Saanen $\times$ Hair Goat $F_{1}$ and $B_{1}$ crossbred kids than in indigenous Hair Goats, although the differences were not found statistically significant. These slight differences might be related to the dairy goat body characteristics of crossbred kids inherited from Saanen genotype. Similar to the current study, Kosum et al. (2003) also reported that the effects of genotype were not significant on conformation and fatness scores and most of the carcass measurements of Saanen and Bornova kids. There are also studies (Dhanda et al., 1999a; Kadim et al., 2003; Santos et al., 2007) reporting significant genotype effect on the body measurements of different genotypes because of the results of higher carcass measurements of larger breeds and genotypes. As the differences between the three genotypes slaughtered at similar ages in the present study were not statistically significant in terms of conformation and fatness scores and body measurements, it can be stated that crossbreeding Hair Goat with Saanen did not result in a notable improvement in carcass structure.

The MLD section area and backfat thickness of Hair Goat and Saanen $\times$ Hair Goat $\left(F_{1}\right.$ and $\left.B_{1}\right)$ crossbred kids ranged from 5.44 to $6.02 \mathrm{~cm}^{2}$ and 0.24 to $0.28 \mathrm{~mm}$. In terms of MLD section area these results were close to the lowest end of those reported by Dhanda et al. (1999a) for crossbreds of Boer, Angora, Saanen and Feral breeds producing Capretto carcasses $\left(6.5-8.7 \mathrm{~cm}^{2}\right)$ and the backfat thickness results of the present study are much lower than the reported range. Both MLD section area and backfat thickness results in the present study are generally low, probably showing the weakness of the genotypes in responding to intensive fattening.

Subcutaneous fat colour results of kids are presented in Table 3. Although the differences between Hair Goat and Saanen $\times$ Hair Goat $F_{1}$ and $B_{1}$ kids were not statistically significant, it was observed that the redness level slightly increased and yellowness level slightly decreased by the increase in the Saanen genotype in crossbred kids.

Carcass joint characteristics and dissected leg compositions. Effects of genotype were not statistically significant on weights and percentages of carcass 
joints (Table 4). In terms of valuable carcass parts like long leg weight and percentage, shoulder and ribs weights $F_{1}$ crossbred kids produced numerically higher results than purebred Hair Goat and $\mathrm{B}_{1}$ crossbred kids. With regard to valuable carcass joint percentages, long leg percentages were $32.48-34.21 \%$, shoulder percentages were $20.87-21.37 \%$ and ribs percentages were 23.54 $24.41 \%$. These results were in accordance with long leg (31.63-33.52\%), shoulder (19.32-19.96\%) and ribs (21.24-24.60\%) results of crossbred kids producing Capretto carcasses at 6-12 kg (Dhanda et al., 1999b). Dhanda et al. (1999b) found the effects of genotype significant on shoulder and ribs percentages while they were not significant on long leg percentage being similar to the result of the present study.

Table 4. Means and standard errors for weights and percentages of carcass joints in Hair Goat and Saanen $\times$ Hair Goat crossbred $\left(F_{1}\right.$ and $\left.B_{1}\right)$ kids

\begin{tabular}{|c|c|c|c|c|c|c|c|}
\hline \multirow{2}{*}{ Item } & \multicolumn{2}{|c|}{ Hair Goat } & \multicolumn{2}{|c|}{ Saanen $\times$ Hair, $F_{1}$} & \multicolumn{2}{|c|}{ Saanen $\times$ Hair, $B$} & \multirow{2}{*}{$F$} \\
\hline & mean & SE & mean & SE & mean & SE & \\
\hline Neck weight, $g$ & 324.89 & 22.57 & 330.29 & 53.20 & 329.25 & 43.46 & $0.005^{\mathrm{NS}}$ \\
\hline Shoulder weight, g & 667.56 & 36.48 & 746.00 & 107.31 & 692.50 & 78.56 & $0.280^{\mathrm{NS}}$ \\
\hline Flank weight, $\mathrm{g}$ & 308.44 & 26.82 & 325.43 & 48.03 & 315.00 & 36.40 & $0.054^{\mathrm{NS}}$ \\
\hline Ribs weight, $g$ & 785.33 & 55.68 & 885.14 & 192.26 & 804.25 & 118.93 & $0.174^{\mathrm{Ns}}$ \\
\hline Long leg weight, $\mathrm{g}$ & 1038.00 & 57.12 & 1215.71 & 193.91 & 1059.00 & 130.84 & $0.536^{\wedge \mathrm{s}}$ \\
\hline Tail weight, $g$ & 10.67 & 0.65 & 11.14 & 1.86 & 9.13 & 0.74 & $0.879^{\mathrm{NS}}$ \\
\hline Kidney weight, g & 34.56 & 1.24 & 36.57 & 4.30 & 38.38 & 2.77 & $0.494^{\mathrm{NS}}$ \\
\hline $\mathrm{KKCF}^{\hat{}}$ weight, $\mathrm{g}$ & 37.00 & 7.14 & 43.00 & 14.47 & 30.38 & 7.55 & $0.401^{\mathrm{NS}}$ \\
\hline Neck, \% & 10.12 & 0.40 & 9.31 & 0.31 & 10.02 & 0.38 & $1.328 \mathrm{Ns}$ \\
\hline Shoulder, $\%$ & 20.87 & 0.21 & 21.28 & 0.55 & 21.37 & 0.51 & $0.421 \mathrm{NS}$ \\
\hline Flank, $\%$ & 9.53 & 0.29 & 9.21 & 0.44 & 9.69 & 0.32 & $0.449^{\mathrm{NS}}$ \\
\hline Ribs, $\%$ & 24.41 & 0.40 & 23.54 & 1.19 & 24.12 & 0.74 & $0.308^{\mathrm{NS}}$ \\
\hline Long leg, \% & 32.48 & 0.44 & 34.21 & 0.64 & 32.38 & 0.55 & $3.427^{\mathrm{NS}}$ \\
\hline Tail, \% & 0.34 & 0.02 & 0.31 & 0.02 & 0.29 & 0.02 & $1.177^{\mathrm{NS}}$ \\
\hline Kidney, \% & 1.10 & 0.06 & 1.09 & 0.09 & 1.23 & 0.09 & $1.010^{\mathrm{NS}}$ \\
\hline $\mathrm{KKCF}^{r}, \%$ & 1.09 & 0.15 & 1.01 & 0.25 & 0.87 & 0.16 & $0.389^{\mathrm{NS}}$ \\
\hline
\end{tabular}

KS - not significant $(\mathrm{P}>0.05) ;{ }^{i} \mathrm{KKCF}$ - kidney knob and channel fat

Dissected long leg compositions of the genotypes are presented in Table 5. In terms of dissected long leg compositions of various genotypes of kids in different studies the percentages of muscle were $58.6-70.0 \%$, total fat 5.4-11.8\% and bone 21.1-31.0\% (Dhanda et al., 1999b, 2003; Oman et al., 1999, 2000; Cameron et al., 2001). In the present study, lean percentages (60.6-63.1\%) were similar, however, fat percentages (4.9-5.3\%) were lower and bone percentages (31.3-33.1) were higher than the results reported in the above studies. Similar to the current study Cameron et al. (2001) did not find the effects of genotype 
Table 5. Means and standard errors for dissected long leg composition in Hair Goat and Saanen $\times$ Hair Goat crossbred $\left(F_{1}\right.$ and $\left.B_{1}\right)$ kids

\begin{tabular}{|c|c|c|c|c|c|c|c|}
\hline \multirow{2}{*}{ Characteristics } & \multicolumn{2}{|c|}{ Hair Goat } & \multicolumn{2}{|c|}{ Saanen $\times$ Hair, $F_{1}$} & \multicolumn{2}{|c|}{ Saanen $\times$ Hair, $B_{1}$} & \multirow{2}{*}{$\mathrm{F}$} \\
\hline & mean & SE & mean & $\mathrm{SE}$ & mean & $\mathrm{SE}$ & \\
\hline$\overline{\text { Muscle, } \%}$ & 63.11 & 0.73 & 61.16 & 0.97 & 60.55 & 1.43 & $1.665^{\mathrm{NS}}$ \\
\hline Subcutaneous fat, $\%$ & 3.32 & 0.73 & 3.17 & 0.69 & 2.49 & 0.37 & $0.516^{\mathrm{NS}}$ \\
\hline Intermuscular fat, $\%$ & 1.94 & 0.24 & 1.76 & 0.29 & 2.44 & 0.44 & $1.100^{\mathrm{NS}}$ \\
\hline Total fat, $\%$ & 5.26 & 0.82 & 4.93 & 0.69 & 4.93 & 0.69 & $0.069^{\mathrm{NS}}$ \\
\hline Bone, $\%$ & 31.26 & 1.21 & 33.07 & 1.41 & 33.08 & 1.34 & $0.674^{\mathrm{NS}}$ \\
\hline Other tissues ${ }^{\beta}, \%$ & 0.50 & 0.07 & 0.58 & 0.12 & 0.81 & 0.15 & $1.954^{\mathrm{NS}}$ \\
\hline Muscle/total fat ratio & 14.57 & 2.26 & 13.96 & 2.08 & 14.27 & 2.20 & $0.019^{\mathrm{NS}}$ \\
\hline Muscle/bone ratio & 2.05 & 0.10 & 1.88 & 0.10 & 1.86 & 0.10 & $1.197^{\mathrm{NS}}$ \\
\hline
\end{tabular}

significant on muscle and fat percentages in long leg. However, in the studies of Dhanda et al. (1999b, 2003) and Oman et al. $(1999,2000)$ the effects of genotype were significant on the muscle, fat and bone percentages in long leg. Evaluated together with the lower fat deposition in the organs, the lower total fat percentages in the long leg might explain that the total fat deposition in the genotypes in the present study would be low even after intensive fattening.

\section{CONCLUSIONS}

Hair Goat and Saanen $\times$ Hair Goat $\left(\mathrm{F}_{1}\right.$ and $\left.\mathrm{B}_{1}\right)$ crossbred kids produced rather light $(6.49-7.29 \mathrm{~kg})$ carcasses with very low level fatness in intensive fattening after weaning. These results might explain the ineffectiveness of intensive fattening on these genotypes in given environmental conditions.

It is concluded that crossbreeding indigenous Hair Goat with Saanen at $F_{1}$ and $\mathrm{B}_{1}$ levels did not result in any improvement in quality carcass production of kids under an intensive production system. However, for a better understanding of carcass production of these genotypes, carcass characteristics of kids at different slaughter ages should also be taken into consideration.

\section{ACKNOWLEDGEMENTS}

The authors would like to thank Hulya Yalcintan and technical staff of Marmara Livestock Research Institute for their assistance in slaughter and carcass analyses. 


\section{REFERENCES}

AOAC, 1984. Association of Official Analytical Chemists, Official Methods of Analysis. $14^{\text {th }}$ Edition. Washington, DC

Anonymous, 2008. Animal Production Statistics, 2007. Turkish Statistical Institute, Republic of Turkey, Press Release No. 88. Home page address: http://www.turkstat.gov.tr

Boggs D.L., Merkel R.A., 1993. Live Animal Carcass Evaluation and Selection Manual. Kendall/ Hunt Publishing Company, Iowa (USA)

Boyazoglu J., Morand-Fehr P., 2001. Mediterranean dairy sheep and goat products and their quality a critical review. Small Ruminant Res. 40, 1-11

Cameron M.R., Luo J., Sahlu T., Hart S.P., Coleman S.W., Goetsch A.L., 2001. Growth and slaughter traits of Boer $\times$ Spanish, Boer $\times$ Angora, and Spanish goats consuming a concentrate-based diet. J. Anim. Sci. 79, 1423-1430

Colomer-Rocher F., Morand-Fehr P., Kirton A.H., 1987. Standard methods and procedures for goat carcass evaluation, jointing and tissue separation. Livest. Prod. Sci. 17,149-159

Dhanda J.S., Taylor D.G., McCosker J.E., Murray P.J., 1999a. The influence of goat genotype on the production of capretto and chevon carcass. 1. Growth and carcass characteristics. Meat Sci. 52, 355-361

Dhanda J.S., Taylor D.G., McCosker J.E., Murray P.J., 1999b. The influence of goat genotype on the production of Capretto and Chevon carcass. 3. Dissected carcass composition. Meat Sci. 52, 369-374

Dhanda J.S., Taylor D.G., Murray P.J., 2003. Part 1. Growth, carcass and meat quality parameters of male goats: Effects of genotype and liveweight at slaughter. Small Ruminant Res. 50, 57-66

Ekiz B., Ozcan M., Yilmaz A., Tolu C., Savas T., 2010. Carcass measurements and meat quality characteristics of dairy suckling kids compared to an indigenous genotype. Meat Sci. 85, 245249

Fisher A.V., De Boer H., 1994. The EAAP standard method of sheep carcass assessment. Carcass measurements and dissection procedures. Report of the EAAP Working Group on Carcass Evaluation, in cooperation with the CIHEAM Instituto Agronomico Mediterraneo of Zaragoza and the CEC Directorate General for Agriculture in Brussels. Livest. Prod. Sci. 38,149-159

Gursoy O., 2006. Economics and profitability of sheep and goat production in Turkey under new support regimes and market conditions. Small Ruminant Res. 62, 181-191

Johnson D.D., McGowan C.H., 1998. Diet/management effects on carcass attributes and meat quality of young goats. Small Ruminant Res. 28, 93-98

Kadim I.T., Mahgoub D.S., Al-Ajmi D.S., Al-Maqbaly R.S., Al-Saqri N.M., Ritchie A., 2003. An evaluation of the growth, carcass and meat quality characteristics of Omani goat breeds. Meat Sci. 66, 203-210

Kaymakci M., 2006. Goat Breeding. Izmir Sheep-Goat Breeders Association Publications, No. 2. Izmir (Turkey)

Kosum N., Alcicek A., Taskin T., Onenc A., 2003. Fattening performance and carcass characteristics of Saanen and Bornova Male kids under an intensive management system. Czech J. Anim. Sci. $48,379-386$

Oman J.S., Waldron D.F., Griffin D.B., Savell J.W., 1999. Effect of breed-type and feeding regimen on goat carcass traits. J. Anim. Sci. 77, 3215-3218

Oman J.S., Waldron D.F., Griffin D.B., Savell J.W., 2000. Carcass traits and retail display-life of chops from different goat breed types. J. Anim. Sci. 78, 1262-1266 
Ruiz de Huidobro F., Miguel E., Díaz M.T., Velasco S., Lauzurica S., Pérez C., Onega E., Blázquez B., Cañeque V., 2004. Carcass classification in suckling lambs. II. Comparison among subjective carcass classification methods: fatness scales and conformation scales with 0.25 point-intervals. Meat Sci. 66, 135-142

Oman J.S., Waldron D.F., Griffin D.B., Savcll J.W., 1999. Effect of breed-type and feeding regimen on goat carcass traits. J. Anim. Sci. 77, 3215-3218

Oman J.S., Waldron D.F., Griffin D.B., Savell J.W., 2000. Carcass traits and retail display-life of chops from different goat breed types. J. Anim. Sci, 78, 1262-1266

Ruiz de Huidobro F., Miguel E., Díaz M.T., Velasco S., Lauzurica S., Pérez C., Onega E., Blázquez B., Cañeque V., 2004. Carcass classification in suckling lambs. Il. Comparison among subjective carcass classification methods: fatness scales and conformation scales with 0.25 point-intervals. Meat Sci. 66, 135-142

Santos V.A.C., Silva A.O., Cardoso J.V.F., Silvestre A.J.D., Silva S.R., Martins C., Azevedo J.M.T., 2007. Genotype and sex effects on carcass and meat quality of suckling kids protected by the PGI "Cabrito de Barroso". Meat Sci. 75, 725-736

SPSS, 1999. Statistical Package for the Social Sciences, Release 10.0. SPSS Inc. Chicago, IL

Yalcin B.C., 1986. Sheep and Goats in Turkey. FAO Animal Production and Health Paper, 60. Rome (Italy)

Yilmaz A., Ozcan M., Ekiz B., Akgunduz M., 2002. Investigations on the possibility of improving the meat production by crossbreeding Turkish Merino, Chios and Kivircik sheep breeds 2 . Fattening, slaughter and carcass characteristics of lambs. Turk. J. Vet. Anim. Sci. 26, 13331340 